\title{
TSUNAMI SHOALING THEORY
}

\author{
KALLE M. LAMPELA \\ Lamprotek Oy, Finland
}

\begin{abstract}
When a kilometers-long tsunami wave approaches the coast, the amplitude of the tsunami wave will increase according to Green's law, depending on the depth of the seawater. Near the shoreline, the increasing tsunami wave sucks from the front seawater and it will withdraw. The sea bottom will open, creating a drawback phenomenon. The drawback flow and the propagating wave front will collide and will form a wave with a sharp drop downwards. The tsunami break wave starts flowing rapidly to the shoreline. To simulate the situation, we can imagine a virtual dam break (theory by Ritter). As a result, we can use the rules for tsunami wave break theory to calculate an emerging massive flow. The velocity of the break wave can be obtained according to the "dam wall break flow" theory. By these rules, the flow velocity, the parabolic form of flowing water surface, the depth of the sea water at shoreline, the duration, the level of the maximum run-up height onshore and flow loading for buildings can all be calculated. The whole aforementioned shoaling process is presented by easily understandable figures. A simplified calculation example is presented based on the Asian tsunami of 2004 in Xaaphuun in Somalia, from which we have a lot of input data from 0.25-degree-shallow shore. The third and strongest drawback of the tsunami was $1300 \mathrm{~m}$ long and $6 \mathrm{~m}$ deep. Knowing the shoreline velocity $(11 \mathrm{~m} / \mathrm{s})$ and estimating the flow friction, we can calculate the depth of water at shoreline, the volume flow, the timing and the average run-up height onshore. The results were in accordance with real data. Also, an explanation will be formulated for the reason why the city of Faro was spared in the Lisbon earthquake and tsunami in 1755 . The tsunami shoaling process includes shoreline approaching increasing tsunami wave, drawback, collision of flows, virtual dam break, massive flow to the shoreline and run-up onshore.
\end{abstract}

Keywords: tsunami, shoaling, drawback, dam break wave, kinetic energy, run-up.

\section{INTRODUCTION}

A tsunami consists of three phases: tsunami generation, propagation and shoaling. The velocity of the propagation of the long-distance tsunami in the constant sea depth is:

$$
U=\sqrt{D g}
$$

where $D$ is seawater depth and acceleration due to gravity is $g=9.81 \mathrm{~m} / \mathrm{s}^{2}$. The propagation velocity will be, in seawater depth of $4 \mathrm{~km}, 713 \mathrm{~km} / \mathrm{h}$ and in seawater depth of $10 \mathrm{~m}$, theoretically only $36 \mathrm{~km} / \mathrm{h}$.

The tsunami propagation theory for constant sea depth is linear and not proper for shoaling of the rising seafloor, where the theory has been said to be nonlinear [1], [3], [11], [13]. Nonlinear theories lead to mathematical difficulties without practical results. When a tsunami wave front is approaching a shallow shore, the wave height will increase with rising seabed according to Green's law [2]:

$$
\frac{H 1}{h 1}=\left(\frac{d 1}{D 1}\right)^{0.25},
$$

where $H_{1}$ and $h_{1}$ are wave heights and $D_{1}$ and $d_{1}$ are corresponding water depths (Fig. 1). Waves get slower, shorter and higher. The general mistake is to assume wave's continuity at the coastline. 


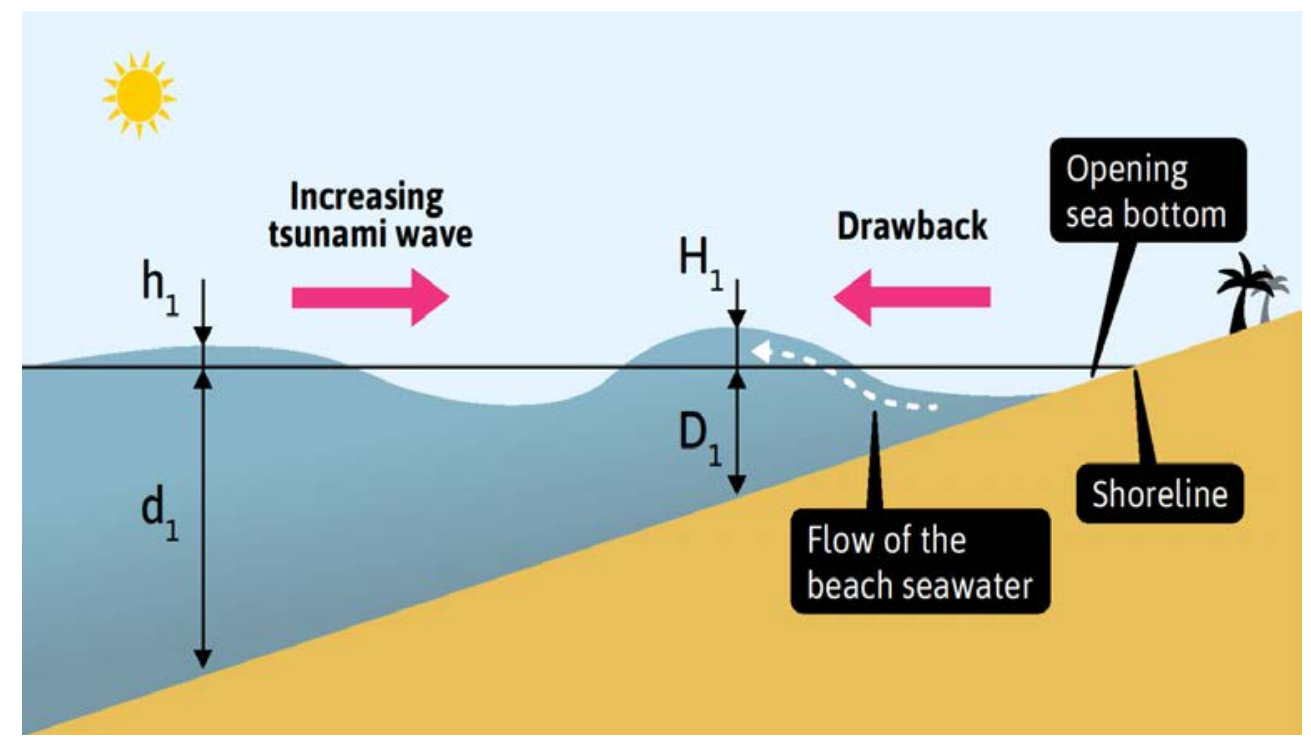

Figure 1: Tsunami wave rises with drawback.

In the shoaling theory it is very important to know the details of flow for saving human lives and preventing damages to property. A good theory also helps to find correct rules and dimensions of the shoreline buildings and structures.

The novelty in this article is that the tsunami waves coming from the ocean cannot reach the shallow shore because of the water drawback and tsunami waves' break according to dam break theory. After breaking the water masses are flooding to the shore causing great disaster.

First, a shoaling theory for the shallow shore, where the seabed slope will be some degrees, will be presented, then for the deep shore and finally for a very deep shore. In the following, the principles of the "Tsunami Shoaling Theory" will be demonstrated with figures and some general equations and calculation examples.

\section{SHOALING OF THE VERY SHALLOW SHORE}

Shoaling can be divided into two phases: (1) the tsunami wave's water rises on the offshore due to the drawback, and (2) the tsunami wave's water breaks resulting in a huge water flow on the dry seabed to shoreline.

When tsunami waves approach ocean shoreline, seawater first withdraws and water flows seaward forming the drawback. The volume of drawback water could be more than 1 million $\mathrm{m}^{3}$, which means 1 million tons of seawater. The amount of seawater depends on how much energy the tsunami wave has.

The first and partly second wave lose tsunami wave's energy by lifting seawater from the sea level while approaching the shore [16]. The first wave has a low drawback and it will be detected only in very shallow shore or beach [4], [12]. The second wave loses also wave energy and generally the third wave is the strongest one. Often only two tsunami waves can be detected.

In tsunami drawback, seawater will flow to the open ocean and will hit to the edge of the kilometers-long tsunami wave. In the collision there will be a sharp drop of the seawater as in the waterfall (Fig. 2). 


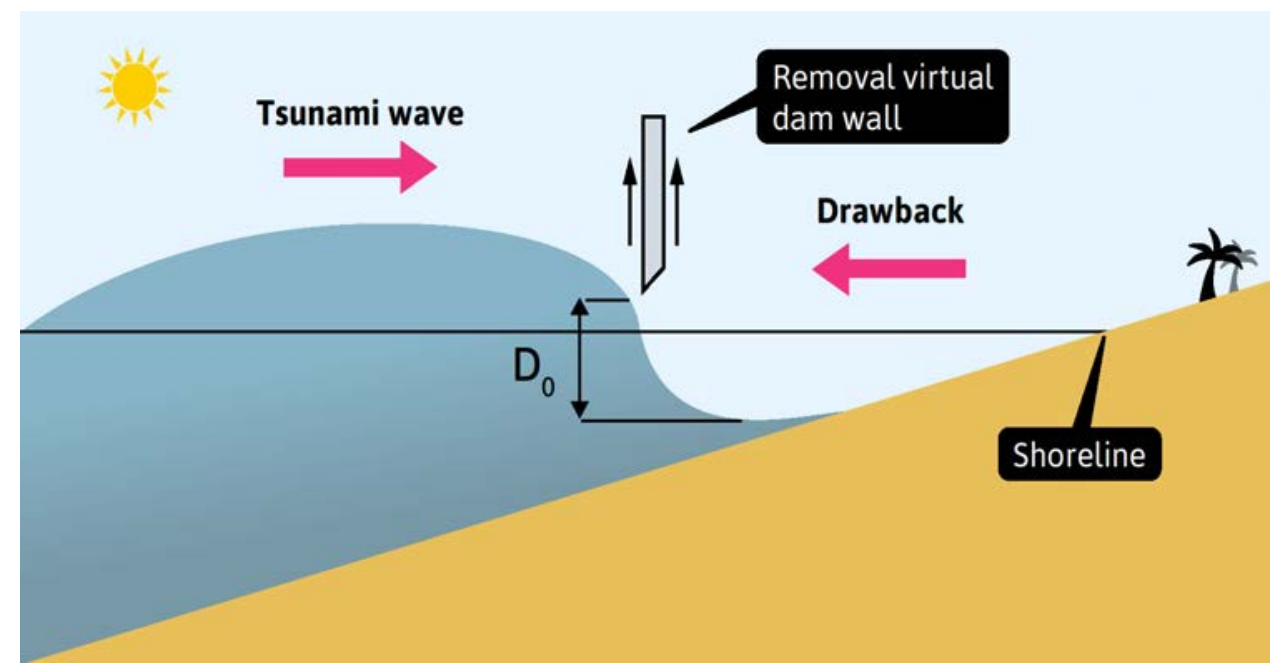

Figure 2: Tsunami wave breaks as a flow from dam wall break.

In this situation the water will approximately behave like water of a dam wall break. The water flows as a flood wave to the shore at velocity $V$ according to the dam break theory [5], [6]. According to dam break theory, flood velocity to plain shore is given by:

$$
V=2 \sqrt{D_{0} g}
$$

where $V$ is the flood flow velocity in $\mathrm{m} / \mathrm{s}, D_{0}$ is total water drop height in $\mathrm{m}$ and $g$ acceleration due to gravity in $\mathrm{m} / \mathrm{s}^{2}$. If the total drop including the height of drawback and tsunami is altogether $D_{0}=5 \mathrm{~m}$, the shoreward velocity on the sea in the breaking point is $V_{1}=14 \mathrm{~m} / \mathrm{s}$ $(50 \mathrm{~km} / \mathrm{h})$. The velocity of the negative wave is half of the positive wave $V_{2}=V_{1} / 2=7 \mathrm{~m} / \mathrm{s}(25 \mathrm{~km} / \mathrm{h})$.

The water flow of the rising seabed will be similar to an open channel flow upwards. The frictionless ideal dam break flow equation (Fig. 3) is:

$$
\frac{x}{t \sqrt{g D_{0}}}=2-3 \sqrt{d / D_{0}}
$$

where $x$ is the horizontal positive distance from breakpoint, $D_{0}$ the height of waterfall drop, $d$ the water depth at time t. The dam break wave has also a negative wave. The breaking wave profile is parabolic. The wave tip region [7], [8] can be noticed in many tsunami videos as front turbulence edge (Fig. 4). The velocity of the open channel flow upwards is given by:

$$
\frac{V}{\sqrt{g D_{0}}}=2+\left(S_{0}-S_{f}\right) \sqrt{\frac{g}{D_{0}}} t
$$

where $S_{0}=\sin \theta$, positive downwards, negative upwards, and $S_{\mathrm{f}}$ is friction.

Point $\mathrm{C}$ in Fig. 3 has, during flow, constant height $h_{C}$, where flow velocity is:

$$
V_{C}=(2 / 3) \sqrt{g D_{0}}
$$

and volume flow:

$$
Q=8 / 27 D_{0} \sqrt{g D_{0}}
$$




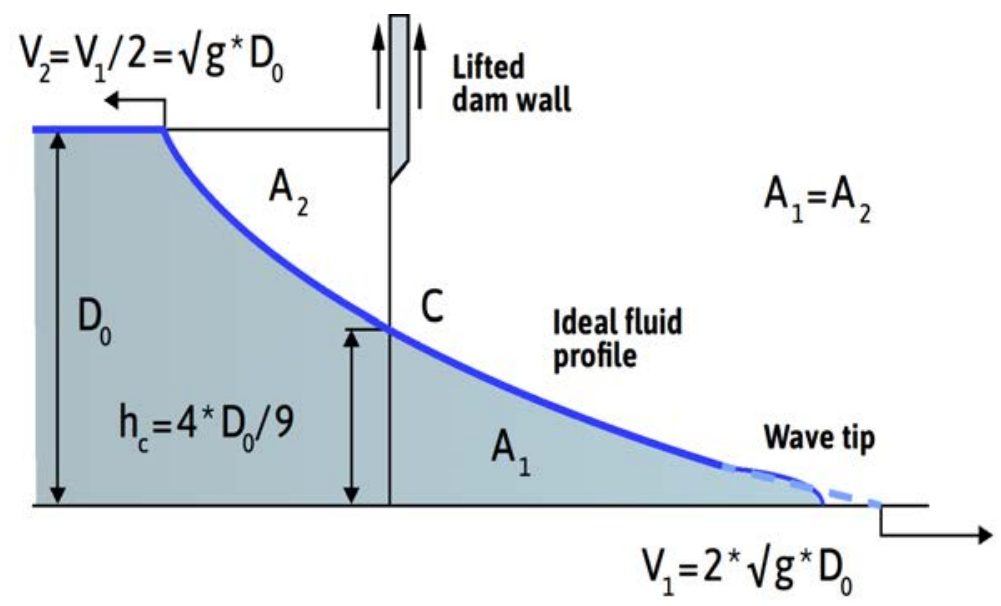

Figure 3: Visualization of the dam wall break flow.

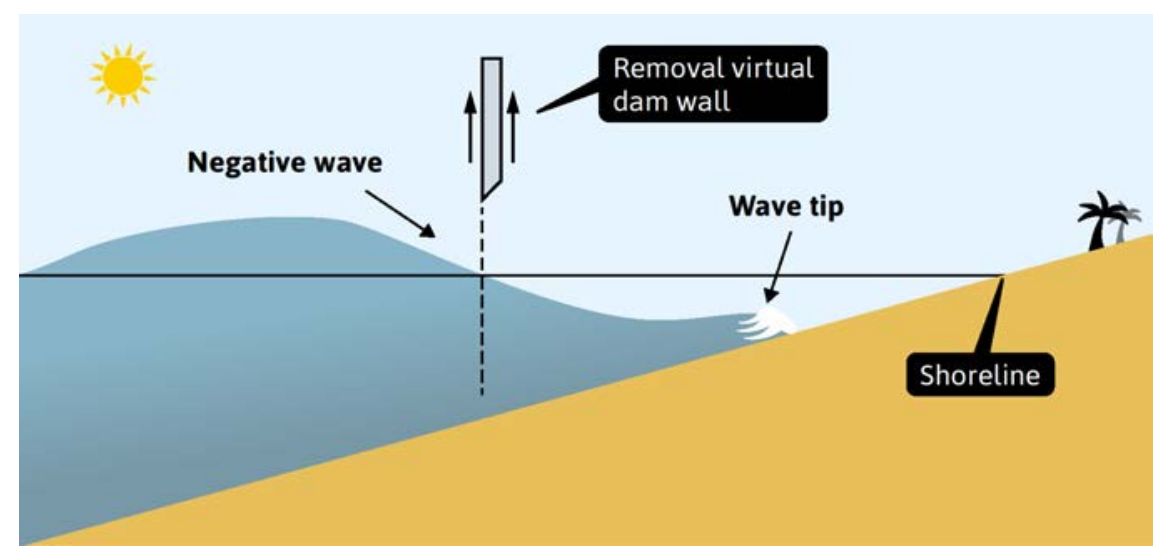

Figure 4: Tsunami break wave flow to the shoreline.

\section{EXAMPLES}

\subsection{Asian tsunami 2004 in Africa}

As a first example, the 2004 Asian tsunami in Xaafuun, a Somalian city in the Horn of Africa, is considered [4]. The initial conditions were: drawback of the third wave was $1300 \mathrm{~m}$, depth $6 \mathrm{~m}$, shoreline water velocity $11 \mathrm{~m} / \mathrm{s}$ and slope of rising seafloor 0.25 degrees.

If we assume the height of $1.7 \mathrm{~m}$ for a kilometer-long tsunami wave on the coast area, we can simulate tsunami shoaling. When the drop of drawback and wave height together is $D_{0}=6+1.7=7.7 \mathrm{~m}$, the dam break velocity is $V=17.4 \mathrm{~m} / \mathrm{s}$.

Seawater flow slows down in about 2 minutes to the shoreline at the velocity of $11 \mathrm{~m} / \mathrm{s}$. The time to flow stopping on shore is about 4 minutes, the run-up height is $4 \mathrm{~m}$ about $0.8 \mathrm{~km}$ from shoreline. In simulation it is assumed a 0.25 -degree slope onshore and a friction factor of $S_{f}=0.0025$ (Fig. 5). The calculation result depends strongly on seabed friction [10]. 


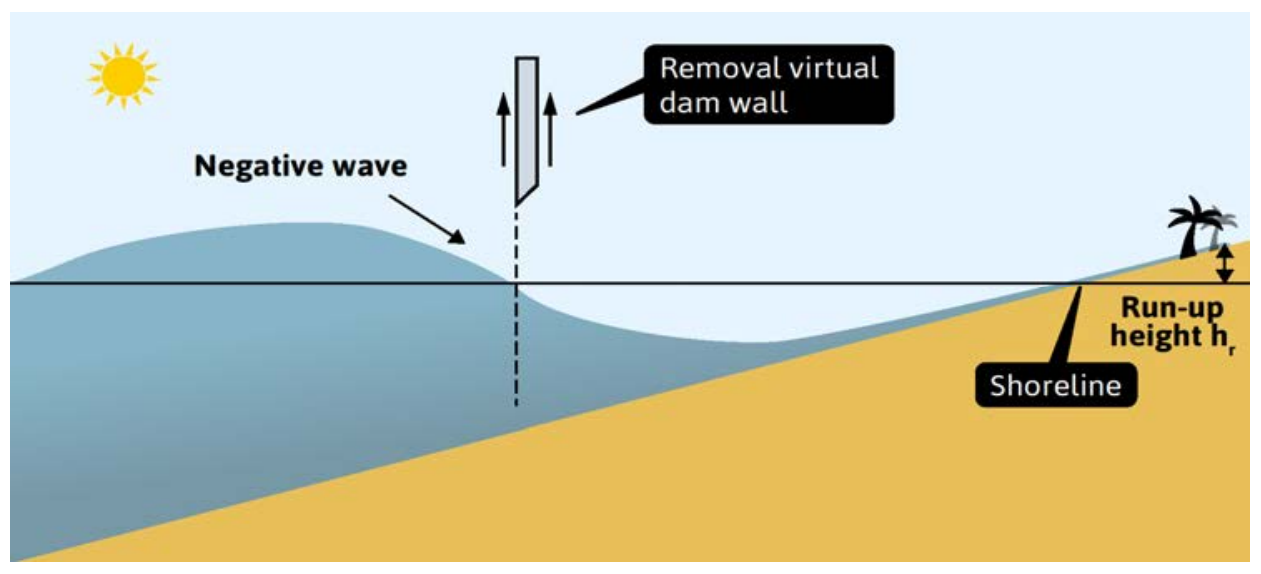

Figure 5: Tsunami break wave flow to run-up height.

The depth of the water flow at shoreline during run-up was $0.85 \mathrm{~m}$, which at a water velocity of $11 \mathrm{~m} / \mathrm{s}$ means $9.35 \mathrm{~m}^{3} / \mathrm{s}$ per $1-\mathrm{m}$ shoreline. For the half-kilometer-long shoreline in Xaafuun, this means nearly 20 million $\mathrm{m}^{3} / \mathrm{h}$ and tons of water. It is understandable, that the walls of houses along the shoreline break due to the fast-moving seawater. According to the simulation the seawater flow on shoreline was supercritical with Froude number $F_{r}=3.8$. The developed kinetic energy can be dissipated, for example, by "a hydraulic jump".

\subsection{Portugal south coast tsunami 1755}

As a second example we consider the earthquake of 1755 which hit the city of Faro in southern Portugal [9]. While the neighboring cities of Olhao and Tavira experienced the destructive tsunami after the earthquake, the city Faro was unaffected by the tsunami. Faro, in fact, was protected by wetland known nowadays as the Ria Formosa nature park with sand banks, barrier islands and marches, which caused a big dissipation of the kinetic tsunami energy. Faro survived the tsunami, which was a miracle at that time of history.

\section{SHOALING OF THE SHALLOW SHORE}

When the seawater depth is from $10 \mathrm{~m}$ to $30 \mathrm{~m}$, the velocity of the approaching tsunami wave is lower and the wave starts to suck water from the front lifting the height of the tsunami wave (Fig. 6). Depending on the tsunami wave's lower velocity, the phenomenon of the negative wave drawback starts to grow. The flow of the virtual dam break directs to the open ocean. The drawback velocity must be faster than the wave velocity $\left(V_{d}>V_{\text {wave }}\right)$ and the drawback phenomenon starts (Fig. 7). In the case of deep shore, no seawater withdraws at the shoreline.

The flow process continues until the drawback touches the seabed or the shoreline. The flow of the virtual dam break will start at the velocity (Fig. 8):

$$
V=2 \sqrt{g D_{t}}
$$

where $D_{\mathrm{t}}=H+h$.

The drawback phenomenon changes the vertical movement of the seawater to a horizontal flood wave. This is the fundamental phenomenon in the tsunami shoaling due to the horizontal flow. 


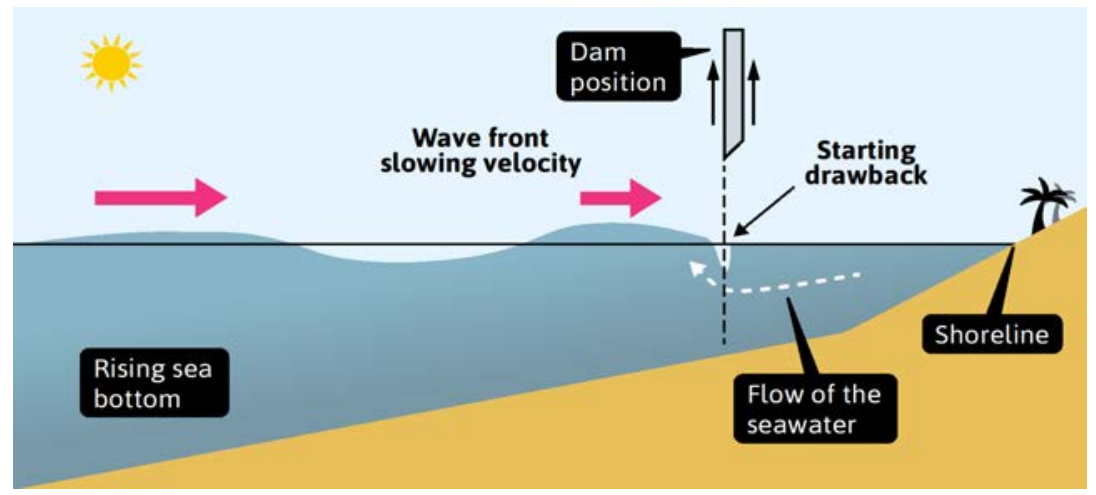

Figure 6: Starting drawback of the shallow shore.

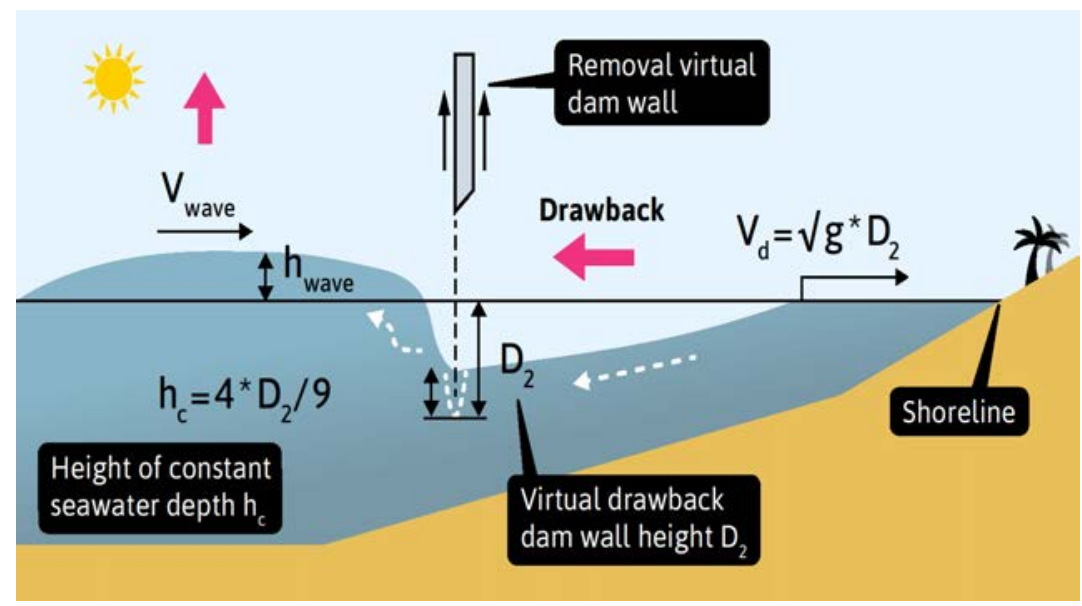

Figure 7: Drawback of the virtual dam break flow to the open ocean.

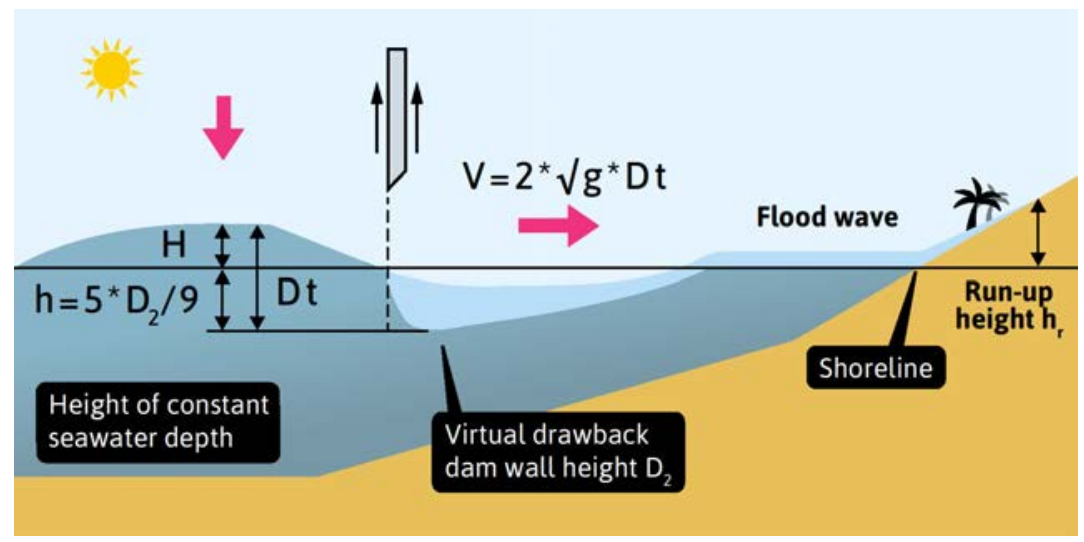

Figure 8: Tsunami flood wave of the shallow shore. 


\section{SHOALING OF THE DEEP SHORE}

Very deep shore - depth over $30 \mathrm{~m}$ - does not have drawback and no horizontal flood and only some meters rise of the seawater because of the high velocity of the tsunami wave.

The drawback phenomenon reduces energy of the first tsunami wave and partly second wave. The third tsunami wave is the biggest one. The first wave is weak and can be seen only on a very shallow shore or beach. That is why many times only two tsunami waves will be detected.

In the open ocean, the tsunami wave height is very low; because of the high velocity and long length of the wave, there is no possibility for sucking enough seawater from the wavefront.

\section{CONCLUSIONS}

Tsunami shoaling theory explains in a simple and understandable way the whole tsunami shoaling process: increasing tsunami wave, drawback, collision of tsunami wave and drawback flow, virtual dam break, massive seawater flow to the shoreline and finally run-up flow onshore.

The results of calculation rules are velocity, depth, volume, kinetic energy, run-up height and the exact times of the shoaling waves. Simulation of different levels of tsunamis is simple by changing the height of seawater drop on the ocean.

With the help of this theory one can innovate and calculate different methods to mitigate or prevent tsunami damages and save human lives. The impact of the kinetic water forces on the coastline buildings and structures [14], [15] can be calculated and simulated according to present shoaling theory.

The shoaling theory presented here does not support the prevailing shoaling theory of the tsunami waves. These tsunami waves are coming to the shallow shore by keeping the shape of the original tsunami waves up to shoreline. In the presented shoaling theory, a tsunami wave will break before the shoreline according to dam break flow theory.

The accuracy of the presented theory depends strongly on the seabed bathymetry and onshore topography. A rough seabed can slow down the coastline flow velocity by $20-30 \%$. The presented theory is based on plain rising seabed because of the corresponding simplicity of the shoaling theory. The most important thing is to find the main influencing general variables that affect the tsunami shoaling. Knowing the most important variables and local conditions can dissipate and prevent damages of the tsunami.

The seawater movement of the tsunami wave is only vertical in the open ocean. When the tsunami wave approaches the shallow shore, the seawater flow will become strongly horizontal. This phenomenon is clearly noticeable in the photos and videos of the tsunamis on the internet.

The tsunami shoaling theory of the very shallow, shallow and deep shore has been described separately.

The seawater flows and kinetic forces on the shore structures and buildings can be simulated by the simple calculation rules with varying tsunami intensities.

The key point presented in the theory is the combination of the tsunami and the dam break flow theory in a creative way.

\section{REFERENCES}

[1] Ward, S.N., Tsunami. Encyclopedia of Solid Earth Geophysics, Springer Press, 2010.

[2] Green. G., On the motion of waves in a variable canal of small depth and width. Transactions of the Cambridge Philosophical Society, 6, 457-462, 1838. 
[3] Levin, B.W. \& Nosov, M.A., Physics of Tsunamis, 2nd ed., Springer International Publishing, 2016.

[4] Fritz, H.M. \& Borrero, J.C., Somalian field survey after December 2004 Indian Ocean Tsunami. Earthquake Spectra, 22(3), 219-233, 2006.

[5] Chanson, H., Environmental Hydraulics of Open Channel Flows, Elsevier Butterworth-Heinemann, 2004.

[6] Chanson, H., Analytical solution of dam break wave with flow resistance. Application to tsunami surges. Proceedings of the 31st IAHR Biennial Congress, pp. 3341-3353, Seoul, 2005.

[7] Chanson, H., Analytical solutions of laminar and turbulent dam break wave. Proceedings of the International Conference on Fluvial Hydraulics, vol. 1-2, River Flow, 2006.

[8] Chanson, H., A simple solution of the laminar break wave. Journal of Applied Fluid Mechanics, 1(1), pp. 1-10, 2008.

[9] Nunes, M., Ferreira, O. \& Luis, J., Tsunami vulnerability zonation in the Algarve coast (Portugal). Journal of Coastal Research, 1(56), pp. 876-880, 2009.

[10] Conde, D.A.S., Babtista, M.A.V., Sousa Oliveira, C. \& Ferreira, R.M.L., A shallowflow model for the propagation of tsunamis over complex geometries and mobile beds. Natural Hazards and Earth System Sciences, 13(10), pp. 2533-2542, 2013.

[11] Aydin, B. \& Kanoglu, U., Analytical solution for nonlinear shallow-water wave equations. Pure and Applied Geophysics, 174(8), pp. 3209-3218, 2012.

[12] Lampela, K.M., Theory of tsunami multi drawback and inundation on the coastline. Presented at 15th World Conference on Earthquake Engineering, Lisboa, 2012.

[13] Lampela, K.M., Pyörähdyssymmetrisen Rakenteen Epälineaarinen Lämpöjännitysanalyysi Elementtimenetelmällä (Nonlinear Thermal Stress Analysis of the Axisymmetric Vessel by Finite Element Method), Master's Thesis, University of Oulu, 1976.

[14] Chock, G.Y.K., The new chapter 6 on tsunami loads and effects in ASCE 7-16. Journal of Structural Engineering, 142(11), 2015.

[15] Mase, H., Kimura, Y., Yamakawa, Y., Yasuda, T., Mori, N. \& Cox, D., Were coastal defensive structures completely broken by an unexpectedly large tsunami? A field survey. Earthquake Spectra, 29(S1), pp. S145-S160, 2013.

[16] Coastal Carolina University, Oceans in Motion: Waves and Tides, Coastal Carolina University. https://ci.coastal.edu/ sgilman/770Oceansinmotion.htm. 